\title{
ANALISIS PROMOSI UNTUK TERCAPAINYA TARGET PENJUALAN PRODUCT PUREBABY PT. ANTAR MITRA SEMBADA CABANG LAMPUNG
}

\author{
PROMOTION ANALYSIS TO ACHIEVE SALES \\ TARGET PRODUCT PUREBABY \\ PT. ANTAR MITRA SEMBADA of LAMPUNG BRANCH OFFICE
}

\author{
Oleh: \\ Melan Susanty Purnamasari \\ Yunita Widhawary \\ Jurusan Ilmu Administrasi Niaga Universitas Tulang Bawang - Lampung \\ E-mail: meilan.susanty@gmail.com
}

\begin{abstract}
Promotion strategies which used by PT. Antar Mitra Sembada product Purebaby to promote and sell product was not maximal that caused the company's sales target problem that has not been achieved and costumer coverage is still narrow. The purpose of this research is to determine the promotional strategies that can increase product sales of product Purebaby. This type of research is using descriptive-qualitative. Data collection techniques using semistructured interviews by involving 10 informants, consist of 4 costumers, 4 agents personal reseller, and 2 marketing expert. The collection of data is also supported by documentation in the form of photographs with informants and internal data firm. Technical analysis of the data in this research consists of 3 stages: data reduction, data presentation, and conclusion. The results showed that PT. Antar Mitra Sembada need of repair and upgrading basic campaign strategyin 8 models of the promotional mix. There are 5 models of promotional mix was chosen as the focus of PT. Antar Mitra Sembada product Purebaby improvement promotional strategies which still in startup business, namely Events, Direct Marketing, Sales Promotion, Interactive Online Marketing, and Word Of Mouth Marketing, As for the third promotional mix, Personal Selling, Public Relations and Publicity, And Advertising, is not become the focus of PT. Antar Mitra Sembada promotional strategies.
\end{abstract}

Keywords: promotion, promotion strategy, promotional mix

\begin{abstract}
ABSTRAK
Strategi promosi yang digunakan PT. Antar Mitra Sembada product Purebaby selama ini dirasa belum maksimal yang ditandai dengan masalah target penjualan perusahaan yang belum tercapai dan cakupan costumer yang masih sempit. Tujuan penelitian ini adalah untuk mengetahui strategi promosi yang dapat meningkatkan penjualan product Purebaby. Jenis
\end{abstract}


penelitian yang digunakan adalah eskriptif-kualitatif. Teknik pengumpulan data dengan menggunakan metode wawancara semi terstruktur yang melibatkan10 informan, yang terdiri dari 4 Konsumen, 4 Agen Perorangan/ Personal reseller Purebaby, 2 Ahli Marketing. Pengumpulan data didukung pula dengan dokumentasi berupa foto-foto data perusahaan yang relevan. Teknik analisis data dalam penelitian ini terdiri dari 3 tahap, yaitu :reduksi data, penyajian data, dan penarikan kesimpulan. Hasil penelitian menunjukkan bahwa PT. Antar Mitra Sembada membutuhkan perbaikan dan peningkatan strategi promosi yang mendasar pada 8 model bauran promosi. Terdapat 5 model bauran promosi yang terpilih sebagai fokus perbaikan strategi promosi PT. Antar Mitra Sembada produk Purebaby yang masih startup business, yaitu Acara (Event), Pemasaran Langsung, Promosi Penjualan, Pemasaran Interaktif Online, dan Pemasaran dari Mulut ke Mulut. Sedangkan untuk 3 promosi lainnya, yaitu Penjualan Personal, Hubungan Masyarakat dan Publisitas, dan Iklan, tidak menjadi fokus strategi promosi PT. Antar Mitra Sembada yang harus diperbaiki/ditingkatkan dalam jangka waktu dekat.

Kata Kunci: promosi, strategi promosi, bauran promosi

\section{PENDAHULUAN}

\subsection{Latar Belakang Masalah}

Purebaby PT. Antar Mitra Sembada adalah perusahaan yang bergerak dalam industri produk kesehatan dan perlengkapan bayi dan anak. Tidak ada yang lebih menyenangkan bagi ibu-ibu selain memberikan yang terbaik bagi bayi dan anak kesayangannya. Setiap harinya, ibu yang baik selalu memberikan perhatian, waktu dan energi untuk memberikan semua hal yang terbaik bagi bayi dan anaknya agar kelak di kemudian hari dapat menjadi anak dan manusia yang sehat. Atas dasar kebutuhan para ibu yang perduli dengan kesehatan bayi dan anaknya, maka Purebaby meluncurkan berbagai produk kesehatan untuk bayi dan anak di Indonesia dengan standard bermutu tinggi sebagai solusi untuk para ibu yang menginginkan produk dengan standard istimewa. Berbeda dengan layaknya produk bayi dan anak di Indonesia, Purebaby menawarkan berbagai keunggulan dan keistimewaan produknya untuk menjamin kualitas produk dengan standard kesehatan international untuk bayi dan anak :

1. Penggunaan material yang aman untuk bayi dan anak.
Kategori Materi Low Hazard Eropa 0-2. Karena kulit bayi dan anak yang sensitif dan belum sekuat manusia dewasa, maka perlu dipilih materi yang tidak menimbulkan iritasi pada kulit jikalau di pakai setiap hari dalam jangka panjang. Produk Purebaby dan Purekids dirancang khusus dengan bahan premium yang mempunyai kategori hazard yang sangat rendah 0-2 sehingga aman untuk bayi dan anak.

2. Non SLS

SLS adalah bahan dasar aktif atau detergen yang berbahaya yang dapat menyerap dan mengikis kelembapan kulit. Dengan kandungan sulfaktan yang sangat berbahaya bagi kesehatan kulit serta berdampak buruk dan memicu kanker untuk efek jangka panjang jika pemakaiannya secara terus-menerus. Maka semua produk Purebaby tidak mengandung SLS.

3. Non Paraben dan Non Alcohol

Paraben adalah pengawet sintesis yang berbahaya. Sedangkan Alcohol adalah bahan yang mengiritasi kulit bayi dan anak sehingga menimbulkan alergi pada bayi dan anak, sehingga Produk Purebaby tidak menggunakan. Dianjurkan kepada para ibu untuk 
melihat komposisi produk untuk membandingkan dan mempelajari kandungan dalam produk bayi dan anak, dan pastikan memilih produk dengan kriteria sesuai diatas demi kesehatan bayi dan anak.

4. Produksi produk dengan standard sterilitas industri farmasi.

Untuk memastikan kualitas produk bayi dan anak yang baik, maka proses produksi perlu dilakukan dalam lingkungan bersih dari kuman dan mengikuti prosedur proses produksi sesuai dengan standard farmasi. Produk Purebaby di produksi di fasilitas dengan standard sterilitas industry farmasi untuk memastikan sterilitas dan dilakukan proses control produksi dan pengecekan kualitas produk sesuai dengan standard Good Manufacturing Practice Farmasi. Dengan filosofi bahwa untuk bayi dan anak lebih baik berhati-hati dibandingkan memberikan yang bisa beresiko terhadap kesehatan bayi dan anak. Maka Purebaby memberikan perlindungan optimal dan premium kepada bayi dan anak dengan semboyan : Premium Care For Baby.

Project promosi yang digunakan Purebaby selama ini dirasa belum maksimal yang ditandai dengan masalah target penjualan perusahaan yang belum tercapai dan cakupan costumer yang masihsempit. Perusahaan bermaksud menjadi pendatang baru sekaligus menjadi penantang pasar pada industri ini dengan strategi differensiasi.

Tabel 1. Target dan Realiasi Penjualan Produk Purebaby pada PT Antar Mitra Sembada Cabang Lampung Tahun 2014 - 2016.

\begin{tabular}{|c|c|c|c|c|}
\hline $\begin{array}{c}\text { N } \\
\text { o. }\end{array}$ & Thn & $\begin{array}{c}\text { Target } \\
(\mathbf{R p})\end{array}$ & $\begin{array}{c}\text { Realisasi } \\
(\mathbf{R p})\end{array}$ & $\begin{array}{c}\text { \% } \\
\text { Pencapa } \\
\text { ian }\end{array}$ \\
\hline 1. & 201 & 450.000. & 400.222. & 88.93 \\
& 3 & 000 & 350 & \\
\hline 2. & 201 & 550.000. & 490.353. & 96.42 \\
\hline
\end{tabular}

\begin{tabular}{|c|c|c|c|c|}
\hline & 4 & 000 & 300 & \\
\hline 3. & 201 & 650.000. & 600.545. & \\
& 5 & 000 & 250 & 92.39 \\
\hline 4. & 201 & 765.000. & 760.848. & 99.45 \\
& 6 & 000 & 076 & \\
\hline
\end{tabular}

Sumber : PT. Antar Mitra Sembada Cabang Lampung

Hal ini menunjukkan bahwa peluang bisnis di industri produk kesehatan dan perlengkapan bayi dan anak sangat positif. Potensi dan peluang Purebaby untuk berkembang di Indonesia sangatlah besar, oleh karena itu dalam menangkap peluang ini Purebaby harus melalukan promosi yang baik dan sesuai dengan kondisi pasar, dan maka dari itu diperlukan peningkatan dalam project promosi. Dari segi promosi, Purebabys elama ini memiliki beragam strategi promosi mulai dari direct promotion (promosi langsung) berupa pembukaan stand pada event atau bazaar, maupun online promotion melalui bantuan media social online dengan tujuan untuk meningkatkan penjualan dan jumlah konsumen Purebaby PT. Antar Mitra Sembada Cabang Lampung.

\subsection{Tujuan Penelitian}

Tujuan dari penelitian ini yaitu untuk mengetahui promosi apa saja yang dapat meningkatkan penjualan produk Purebaby sehingga tercapainya target penjualan PT. Antar Mitra Sembada Cabang Lampung serta untuk mengetahui bagaimana cara pelaksanaan promosi PT. Antar Mitra Sembada Cabang Lampung tersebut sehingga tercapainya target penjualan produk Purebaby.

\subsection{Rumusan Masalah}

Berdasarkan uraian pada latar belakang, maka masalah yang akan di bahas pada penulisan ini, yaitu :

1. Promosi apa sajakah yang harus dilakukan untuk tercapainya target 
2. enjualan product Purebaby PT. Antar Mitra Sembada Cabang Lampung ?

3. Bagaimana promosi yang dilakukan PT. Antar Mitra Sembada Cabang Lampung sehingga dapat tercapainya target penjualan product Purebaby dengan adanya peningkatan?

\subsection{Metode Penelitian}

Untuk membantu dan membantu dan menunjang penulisan tugas akhir ini, metode yang digunakan yaitu metode pendekatan (case study) karena topik atau masalah yang diteliti membutuhkan studi penelitian yang bersifat deskriptif, intensif, menyeluruh, terperinci dan menghasilkan analisis mendalam dengan cara pengumpulan detil informasi menggunakan berbagai macam prosedur dan sumber data kualitatif atau dengan kata lain bersifat multisumber bukti. Penelitian juga bersifat memperbaiki /memperbaharui dan eksplanatori yang artinya menjawab pertanyaan bagaimana, mengapa, dan apa hasilnya. Adapun tahapan yang dilakukan sebagai berikut :

1. Metode Pengumpulan Data, Pengumpulan data dilakukan dengan 2 cara yaitu wawancara dan dokumentasi. Jenis wawancara terstruktur dan sistematis, adapun dokumentasi diperlukan sebagai pelengkap/ penunjang informasi dalam penelitian.

2. Metode Analisis Data, dengan menggunakan metode analisis kualitatif deskriptif yang terdiri dari 3 tahap. Tahap pertama adalah Reduksi Data, yang diawali dengan peneliti mencari dan mengumpulkan hasil wawancara dan dokumentasi terkait project promosi perusahaan. Tahapan berikutnya adalah penyederhanaan data agar data mudah dipahami dan mudah disajikan, yang dirangkum dalam bentuk tabel reduksi data sehingga memudahkan penarikan kesimpulan akhir. Tahap kedua adalah
Penyajian Data, dilakukan dengan mengkategorikan dan menyusun kumpulan data/informasi agar mendapatkan gambaran utuh dan sistematis untuk memudahkan penarikan kesimpulan dan pengambilan tindakan. Tahap ketiga adalah Penarikan Kesimpulan, yang dilakukan saat peneliti dapat merancang project promosi yang paling sesuai untuk diterapkan Purebaby dengan didukung bukti-bukti kredibel, yaitu apabila Purebaby memiliki akses untuk menerapkan rancangan project promosi yang disusun, dan project promosi yang bisa meningkatkan penjualan Purebaby.

\section{LANDASAN TEORI}

\subsection{Pemasaran}

Pengertian pemasaran menurut Kotler (1997:8) adalah "Suatu proses social manajerial yang didalamnya individu dan kelompok mendapatkan apa yang mereka butuhkan dan inginkan dengan menciptakan, menawarkan dan mempertukarkan produk dengan pihak lain".

Menurut The American Marketing Association, pemasaran adalah proses merencanakan konsepsi, harga, promosi dan distribusi ide, menciptakan peluang yang memuaskan individu dan sesuai dengan tujuan organisasi (Alma, $2007: 5$ ). Kotler dan Keller (2008:5) mendefinisikan pemasaran menurut sudut pandang sosial bahwa pemasaran adalah sebuah proses kemasyarakatan (sosial) di mana individu dan kelompok memperoleh apa yang mereka butuhkan dan inginkan dengan cara menciptakan, menawarkan, dan secara bebas mempertukarkan produk yang bernilai.

Banyak yang menganggap bidang ini indentik atau sama dengan bidang penjualan. Sesungguhnya pemasaran 
memiliki arti yang luas daripada penjualan. Bidang penjualan merupakan bagian dari bidang pemasaran, sekaligus merupakan bagian terpenting dari bidang pemasaran itu sendiri. Pemasaran berarti bekerja dengan pasar untuk mewujudkan pertukaran potensial dengan maksud memuaskan kebutuhan dan keinginan manusia. Jika perusahaan menaruh perhatian lebih banyak untuk terus menerus mengikuti perubahan kebutuhan dan keinginan baru, mereka tidak akan mengalami kesulitan untuk mengenali peluang-peluangnya. Karena para konsumen selalu mencari yang terbaik untuk kehidupannya dan tentu saja dengan harga yang terjangkau dan dengan kualitas yang baik pula, hal itulah yang memicu adanya persaingan yang semakin tajam yang menyebabkan para penjual merasa semakin lama semakin sulit menjual produknya di pasar. Sebaliknya, pihak pembeli merasa sangat diuntungkan karena mereka bebas memilih dari pihak manapun dengan kualitas dan mutu produk yang baik.

\subsection{Bauran Promosi}

Bauran promosi merupakan gabungan arus informasi secara menyeluruh dan hanya dilakukan oleh satu organisasi atau individu tertentu. Ini berbeda dengan komunikasi pemasaran yang bertujuan untuk memuaskan semua pihak. Telah disebutkan bahwa komunikasi pemasaran merupakan pertukaran informasi dua arah antara pihakpihak yang terlibat di dalam perusahaan.

Definisi menurut Wiliam J Stanton (1996:158), "Bauran Promosi adalah satu aspek yang penting dalam menuju pemasaran dan sering dikatakan sebagai proses lanjut ini disebabkan karena bauran promosi dapat menimbulkan rangkaian kegiatan selanjutnya dari perusahaan".

Menentukan variabel promotional mix yang paling efektif merupakan tugas yang sulit dalam manajemen pemasaran, manajemen tidak dapat terlepas dari macam faktor yang mempengaruhinya dalam menentukan kombinasi yang terbaik dari variablevariabel promotional mix (Basu Swastha, $2002: 240$ ).

Alat-alat bauran promosi dikelompokkan menjadi 4 bagian yaitu :

a. Periklanan (Advertising)

b. Promosi Penjualan (Sales Promotion)

c. Publikasi (Publication)

d. Penjualan personal (personal selling)

\subsection{Penjualan Produk}

Penjualan merupakan tujuan utama dilakukannya kegiatan perusahaan. Perusahaan, dalam menghasilkan barang/jasa, mempunyai tujuan akhir yaitu menjual barang/jasa yersebut kepada masyarakat.

Kegiatan penjualan merupakan suatu kegiatan yang harus dilakukan oleh perusahaan dengan memasarkan produknya baik berupa barang atau jasa. Kegiatan pejualan yang dilaksanakan oleh perusahaan bertujuan untuk mencapai volume penjualan yang diharapkan dan menguntungkan untuk mencapai laba maksimum bagi perusahaan.

Menurut Basu Swastha DH (2004: 403) penjualan adalah interaksi antara individu saling bertemu muka yang ditujukan untukmenciptakan, memperbaiki, menguasai atau mempertahankan hubungan pertukaran sehingga menguntungkan bagi pihak lain.

Penjualan menurut Rangkuti (2009:206) adalah pemindahan hak milik atas barang atau pemberian jasa yang dilakukan penjualan kepada pembeli dengan harga yang disepakati bersama dengan jumlah yang dibebankan kepada pelanggan dalam penjualan barang/jasa dalam suatu periode akuntansi. 
Faktor-faktor yang mempengaruhi penjualan menurut Basu Swastha (2005) sebagai berikut:

1) Kondisi dan Kemampuan Penjual

2) Kondisi Pasar

3) Modal

4) Kondisi Organisasi Perusahaan

\subsection{Hubungan Antara Promosi dan Penjualan Produk}

Dalam kegiatan pemasaran yang sangat kompleks dan saling berkaitan yang satu dengan yang lainnya, seperti promosi dan penjualan hendaknya dikelola dengan baik untuk mencapai tujuan perusahaan, yaitu laba. Promosi berfungsi untuk meningkatkan penjualan juga sebagai strategi untuk menjangkau pembeli untuk melakukan pertukaran. Sedangkan penjualan adalah pemindahan barangdan jasa yang dilakukan oleh penjual. Pada umumnya perusahaan yang ingin mempercepat proses peningkatan penjualan akan melakukan untuk mengadakan kegiatan promosi melalui iklan, personal selling, dan publisitas.

\section{METODOLOGI PENELITIAN}

\subsection{Jenis Penelitian}

Penelitian ini menggunakan

jenis/pendekatan penelitian deskriptifkualitatif, yang menitikberatkan pada kedalaman data sehingga peneliti dapat menggali lebih dalam mengenai objek yang diteliti (Sukmadinata, 2009:60), Metode penelitian yang digunakan pendekatan (case study) karena topik atau masalah yang diteliti membutuhkan studi penelitian yang bersifat deskriptif, intensif, menyeluruh, terperinci dan menghasilkan analisis mendalam dengan cara pengumpulan detil informasi menggunakan berbagai macam prosedur dan sumber data kualitatif atau dengan kata lain bersifat multisumber bukti. Penelitian juga bersifat memperbaiki/memperbaharui dan eksplanatori yang artinya menjawab pertanyaan bagaimana, mengapa, dan apa hasilnya.

\subsection{Subjek Penelitian dan Penentuan Sampel/Informan}

Situasi sosial sebagai subjek pada penelitian ini adalah : konsumen yang pernah membeli Purebaby, agen personal reseller Purebaby, dan pakar/ahli Marketing. Penelitian ini menentukan sampel dengan non- probability sampling yang bersifat tidak memberikan peluang yang sama bagi setiap unsur/anggota populasi untuk dipilih menjadi sampel (Bungin, 2013:112). Teknik sampling yang dipilih adalah teknik purposive sampling karena teknik ini bersifat lebih simple/praktis dengan menentukan kriteria sampel terlebih dahulu sehingga membantu peneliti untuk dapat memperoleh sampel yang benar-benar sesuai dengan tujuan penelitian dan relevan dengan masalah penelitian (Sunyoto, 2013). Kriteria pemilihan narasumber/informan penelitian yang diwawancarai pada penelitian ini terdapat pada tabel berikut.

\begin{tabular}{|c|c|}
\hline Sumber & Kriteria \\
\hline $\begin{array}{l}\text { Konsumen } \\
\text { Purebaby }\end{array}$ & $\begin{array}{l}\text { 1. Konsumen } \\
\text { Purebaby yang } \\
\text { sudah pernah } \\
\text { membeli } \\
\text { produk minimal } \\
1 \mathrm{x} \\
\text { 2. Konsumen } \\
\text { Purebaby yang } \\
\text { repeat } \\
\text { order/membeli } \\
\text { produk lebih } \\
\text { dari 1x } \\
\text { 3. Konsumen } \\
\text { Purebaby yang } \\
\text { sering membeli } \\
\text { produk } \\
\text { Purebaby secara } \\
\text { langsung pada }\end{array}$ \\
\hline
\end{tabular}




\begin{tabular}{|c|c|}
\hline & $\begin{array}{l}\text { saat } \\
\text { bazaarlevent } \\
\text { 4. Konsumen yang } \\
\text { sering membeli } \\
\text { produk } \\
\text { Purebaby secara } \\
\text { online. }\end{array}$ \\
\hline $\begin{array}{l}\text { Agen } \\
\text { Perorangan/Person } \\
\text { al reseller } \\
\text { Purebaby }\end{array}$ & 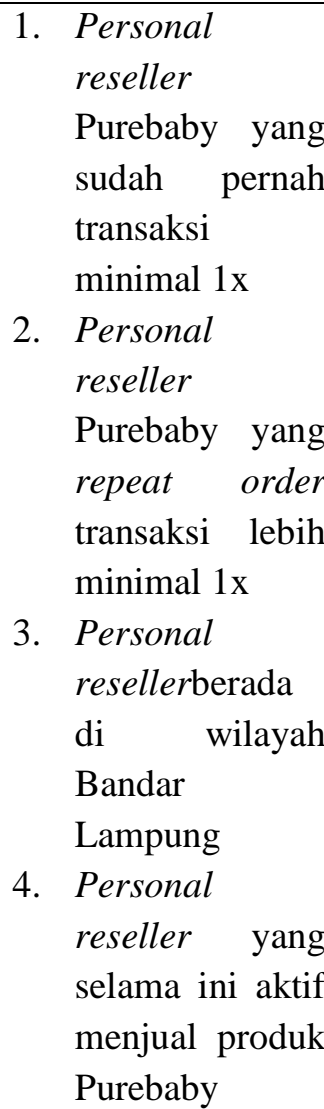 \\
\hline Ahli Marketing & $\begin{array}{l}2 \text { Orang } \\
\text { Marketing } \\
\text { expert } \\
\text { perusahaan mau } \\
\text { berbagi ilmu, } \\
\text { dan menguasai } \\
\text { detail mengenai } \\
\text { marketing/prom } \\
\text { otion. }\end{array}$ \\
\hline
\end{tabular}

\subsection{Metode Pengumpulan Data}

Pengumpulan data dilakukan dengan 2 cara yaitu wawancara dan dokumentasi. Jenis wawancara terstruktur dan sistematis, karena dengan jenis ini peneliti dapat mewawancarai narasumber dengan lebih terstruktur dan terfokus dengan adanya pedoman pertanyaan yang dibuat sebelumnya, sehingga data yang diperoleh mendalam dan kesalahan seperti pertanyaan berulang atau melewatkan pertanyaan dapat dihindari. Dokumentasi diperlukan sebagai pelengkap/penunjang informasi dalam penelitian (Sugiyono, 2013: 196). Sumber data primer pada penelitian ini berupa dokumentasi hasil wawancara yaitu foto bersama informandan rekaman hasil wawancara. Sumber data sekunder pada penelitian ini berupa data internal, studi jurnal terdahulu, dan teori-teori buku.

\subsection{Metode Analisis Data}

Metode analisis data yang peneliti gunakan adalah " metode analisis kualitatif deskriptif dalam" menurut Miles and Huberman Models (Sugiyono, 2014:402) yang terdiri dari 3 tahap. Tahap pertama adalah Reduksi Data, yang diawali dengan peneliti mencari dan mengumpulkan hasil wawancara dan dokumentasi terkait project promosi perusahaan. Data yang telah penelitikumpulkan dari narasumber tersebut akan dikelompokkan dan dilakukan proses pengecekan melalui tringulasi data untuk dipilih lagi berdasarkan kebutuhan dan kesesuaian dengan penelitian, sehingga data yang tidak diperlukan akan disortir/dibuang. Tahapan berikutnya adalah penyederhanaan data agar data mudah dipahami dan mudah disajikan, yang dirangkum dalam bentuk tabel reduksi data sehingga memudahkan penarikan kesimpulan akhir. Tahap kedua adalah Penyajian Data, dilakukan dengan mengkategorikan dan menyusun kumpulan data/informasi agar mendapatkan gambaran utuh dan sistematis untuk memudahkan penarikan kesimpulan dan pengambilan tindakan. Penyajian data yang digunakan dalam penelitian kualitatif ini adalah teks naratif, baik berupa uraian singkat, bagan, tabel, dan hubungan antar kategori yang mudah dipahami. Tahap ketiga adalah 
Penarikan Kesimpulan, yang dilakukan saat peneliti dapat merancang project promosi yang paling sesuai untuk diterapkan Purebaby dengan didukung bukti-bukti kredibel, yaitu apabila Purebaby memiliki akses untuk menerapkan rancangan project promosi yang disusun, dan project promosi yang bisa meningkatkan penjualan Purebaby.

\section{ANALISIS DAN PEMBAHASAN}

Dalam penelitian ini, pembahasan mengenai strategi promosi yang dilakukan oleh PT. Antar Mitra Sembada untuk mencapai target penjualan adalah sebagai berikut :

\section{Acara (Event)}

Acara (event) yang dilakukan PT. Antar Mitra Sembada dilakukan guna mendekatkan PT. Antar Mitra Sembada dengan konsumennya sehingga melalui kegiatan ini diperoleh manfaat baik bagi perusahaan maupun konsumen untuk saling memperoleh informasi mengenai produkproduk PT. Antar Mitra Sembada dan harapan-harapan yang diinginkan oleh konsumen. Acara (event) yang diselenggarakan oleh PT. Antar Mitra Sembada dalam program pengenalan Purebaby kepada masyarakat adalah melalui acara Lomba Menggambar dan Mewarnai di PAUD dan TK, kemudian Event Purebaby and Kids di PAUD dan TK, Seminar dan Simposium, Event Mother and Baby Fair di Outlet-outlet Penjualan Purebaby.

Bentuk promosi melalui aktivitas ini sangat menguntungkan sebab perusahaan dan konsumen dapat bertemu secara langsung.

\section{Pemasaran Langsung (Direct Marketing)}

Pemasaran langsung dapat mendongrak penjualan Purebaby. Pemasaran langsung yang dilakukan oleh PT. Antar Mitra Sembada yaitu menjadi disributor produk
Purebaby dan menjual produknya ke tokotoko, apotik, rumah sakit anak, mall-mall dan minimarket.

Pemasaran langsung juga harus dilakukan dengan membawa tester/sampel produk, brosur, katalog produk, dan kartu nama, yang terdapat penjelasan produk secara lengkap, contact person Purebaby yang bisa dihubungi untuk melakukan order, dan juga terdapat info mengenai media-media sosial online Purebaby.

\section{Promosi Penjualan (Sales Promotion)}

Promosi penjualan (sales promotion) merupakan program dan penawaran khusus dalam jangka pendek yang dirancang untuk memikat para konsumen (kebanyakan langsung kepada konsumen akhir) yang terkait agar mengambil keputusan pembelian yang positif.

Promosi penjualan yang dilakukan oleh PT. Antar Mitra Sembada antara lain promo Buy 1 Get 1 Free, Free Tester, Promo saat Event/ hari besar seperti Natal, Tahun baru, Imlek, dan sebagainya dalam paket/ parcel produk Purebaby, free delivery/free ongkir, promo bazaar, dan promo online terutama di instagram. Sedangkan untuk bentuk Sales Promotion yang harus dieliminasi adalah promo yang berbentuk penukaran fisik, seperti berupa pemberian voucher.

Kelebihan dari program ini adalah konsumen dapat membeli produk dengan harga yang lebih murah. Sementara perbaikan yang harus dilakukan adalah dengan jangkauan promosi yang dilakukan tidak hanya di tempat-tempat tertentu saja namun hendaknya dapat dilakukan di seluruh toko, mall, apotik atau minimarket yang menjual produk Purebaby.

\section{Pemasaran Interaktif (Interactive Online Marketing)}

Bauran promosi Interactive Online Marketing dipilih sebagai salah satu strategi promosi yang penting bagi Purebaby. 
Sebagaian besar konsumen Purebaby memilih untuk memberi produk secara online. Konsumen, reseller, dan distributor juga menyatakan bahwa peningkatan media promosi online harus dilakukan Purebaby. Strategi promosi melalui Interactive Online Marketing sesuai dan sebaiknya menjadi konsentrasi strategi yang harus ditingkatkan oleh Purebaby. Promo melalui media online dapat digunakan untuk memperkenalkan brand dan product, dan membuat dapat terlebih dahulu mengenai atribut yang ada pada produk Purebaby. Keuntungan melalui pemasaran interaktif adalah efektivitas biaya promosi (budget promotion) dan jangkauan promosi yang lebih luas.

Perbaikan strategi promosi Purebaby melalui bauran Interactive Online Marketing salah satunya adalah dengan memilih media-media sosial online tertentu yang paling sering digunakan dan paling direkomendasikan oleh narasumber dan melakukan perbaikan pada kekurangan promosi di media-media sosial online tersebut, antara lain :

\section{a. Instagram \\ b. BBM (Blackberry Messanger) dan Line}

\section{Pemasaran dari Mulut ke Mulut (Word of Mouth Marketing)}

Word of Mouth Marketing (WOM) merupakan salah satu strategi promosi yang efektif karena secara tidak langsung sangat membantu Purebaby dalam mempromosikan produk dari satu orang ke orang lain. Bentuk promosi Word of Mouth Marketing tidak hanya terbatas pada cara konvensional melalui tatap muka tetapi Purebaby bisa memanfatkan media sosial online untuk pelaksanaan WOM ini dalam bentuk testimony. Testimony di media sosial membuat WOM lebih mudah terjadi dan lebih luas jangkauannya. Biasanya konsumen yang memperoleh kepuasan dengan mengkonsumsi suatu produk akan dengan sukarela menceritakan pengalamannya tersebut kepada orang lain. Oleh karena itu produk Purebaby harus terus meningkatkan kualitas produk dan pelayanannya kepada konsumen sehingga konsumen puas dan kemudian secara tidak langsung dapat menjadi agen Word of Mouth Marketing dengan menceritakan hal tersebut kepada orang lain.

Tabel 2. Target dan Realiasi Penjualan Produk Purebaby pada PT. Antar Mitra Sembada Cabang Lampung Tahun 2014 - 2016

\begin{tabular}{|c|c|c|c|l|}
\hline $\begin{array}{c}\text { N } \\
\text { o. }\end{array}$ & Thn & $\begin{array}{c}\text { Target } \\
(\mathbf{R p})\end{array}$ & $\begin{array}{c}\text { Realisasi } \\
(\mathbf{R p})\end{array}$ & $\begin{array}{c}\text { \% } \\
\text { Penca- } \\
\text { paian }\end{array}$ \\
\hline 1. & 201 & 450.000. & 480.222. & 106.71 \\
& 3 & 000 & 350 & \\
\hline 2. & 201 & 550.000. & 622.353. & 113 \\
& 4 & 000 & 300 & .15 \\
\hline 3. & 201 & 650.000. & 690.545. & 106 \\
& 5 & 000 & 250 & .24 \\
\hline 4. & 201 & 765.000. & 790.848. & 103.38 \\
& 6 & 000 & 076 & \\
\hline
\end{tabular}

Sumber : PT Antar Mitra Sembada Cabang Lampung, 2017

Berdasarkan data pada Tabel di atas tampak jelas bahwa pada Tahun 2014-2016 penjualan produk Purebaby pada PT. Antar Mitra Sembada Cabang Lampung selalu berhasil mencapai target, di mana realisasi target tertinggi terjadi pada Tahun 2014 sebesar $113.15 \%$ sedangkan yang terendah pada Tahun 2016 yaitu 103,38\%.

\section{KESIMPULAN DAN SARAN}

\subsection{Kesimpulan}

Berdasarkan hasil analisis dan pembahasan dapat disimpulkan beberapa hal sebagai berikut :

1. PT. Antar Mitra Sembada Cabang Lampung pada Tahun 2016 berhasil mencapai target penjualan produk 
Purebaby. Keberhasilan PT. Antar Mitra Sembada Cabang Lampung dalam menerapkan strategi bauran promosi antara lain melalui acara (event), pemasaran langsung (direct marketing), promosi penjualan (sales promotion), pemasaran interaktif (interactive online marketing) dan pemasaran dari mulut ke mulut (word of mouth marketing).

2. Strategi bauran promosi yang dilakukan oleh PT. Antar Mitra Sembada Cabang Lampung dalam mencapai target penjualan antara lain dilakukan dengan cara:

a. Melalui acara (event) yang dilakukan oleh PT. Antar Mitra Sembada Cabang Lampung.

b. Pemasaran Langsung (Direct Marketing) menguntungkan perusahaan.

c. Promosi penjualan (sales promotion) sangat bermanfaat bagi perusahaan agar calon pembeli dapat tertarik, lalu juga sebagai media pengenalan produk kepada calon pembeli.

d. Strategi promosi pemasaran interaktif (interactive online marketing) sangat efektif bagi perusahaan.

e. Pemasaran dari Mulut ke Mulut (Word of Mouth Marketing) merupakan strategi promosi yang efektif dan tidak memerlukan biaya promosi karena dilakukan melalui rekomendasi dari konsumen yang sudah mencoba dan puas terhadap produk Purebaby dan kemudian mempromosikan produk Purebaby ke orang lain.

\subsection{Saran}

Saran-saran yang dapat dikemukakan sebagai alternatif perbaikan bagi PT. Antar Mitra Sembada Cabang Lampung adalah sebagai berikut:

1. Dewasa ini penggunaan media sosial online sebagai sarana pemasaran semakin berkembang. Oleh karena itu PT. Antar Mitra Sembada Cabang Lampung harus berinovasi melalui start up business sehingga melalui start up business semakin memperluas jangkauan pemasaran Purebaby kemudian di samping itu melalui aktivitas di media internet perusahaan dapat menekan biaya promosi dalam upaya mengenalkan produknya kepada masyarakat.

2. PT. Antar Mitra Sembada secara konsistem harus dapat menjaga kualitas produk dan pelayanannya kepada konsumen, sebab apabila konsumen tidak puas mereka dapat menceritakan ketidakpuasannya tersebut dari mulut ke mulut sehingga dapat merusak image produk dan perusahaan.

\section{DAFTAR PUSTAKA}

Basu, Swastha. 2002. Manajemen Pemasaran. Edisi Kedua. Cetakan kedelapan, Jakarta : Penerbit Liberty

Basu Swastha DH. 2004. Azas-azas Marketing. Yogyakarta: Liberty

Basu Swastha dan Irawan, 2005, Manajemen Pemasaran Modern. Liberty, Yogyakarta

Buchari Alma, 2007, Manajamen Pemasaran dan Pemasaran Jasa, Alfabeta, Bandung

Bungin, B. 2013. Metodologi penelitian social dan ekonomi; format-format kuantitatif dan kualitatif untuk studi sosiologi, kebijakan publik, komunikasi, manajemen, dan pemasaran. Jakarta, ID : Kencana Prenada Media Group

Danang, Sunyoto. 2013. Metodologi Penelitian Akuntansi. Bandung: PT Refika Aditama Anggota Ikapi 
Kotler, Philip. 1997, Manajemen Pemasaran. Edisi Bahasa Indonesia jilid satu. Jakarta: Prentice Hal

Kotler, P. dan K.L. Keller. 2008 Marketing Managemen. Edisi Kedua belas. T.t.p.:t.p

Rangkuti, Freddy. 2009. Strategi Promosi yang Kreatif dan Analisis Kasus Integrated Marketing Communication. Edisi Pertama. Cetakan Pertama. Jakarta : Gramedia Pustaka Utama

Stanton, William. J dan Y. Lamarto. 1996. Prinsip Pemasaran. Edisi 7. Erlangga. Jakarta

Sugiyono, 2013. Metode penelitian pendidikan (pendekatan kuantitatif, kualitatif, dan R\&D). Bandung, ID : Alfabeta

Sugiyono. 2014. Metode Penelitian Pendidikan Pendekatan Kuantitatif, Kualitatif, dan R\&D. Bandung: Alfabeta

Sukmadinata, Nana Syaodih. 2009. Metode Penelitian Pendidikan. Bandung :

Remaja Rosdakarya 